\title{
Minucje nowe sowizrzałowe Maurycjusza Trztyprztyckiego - staropolski kalendarz w krzywym zwierciadle satyry
}

Małgorzata Krzysztofik 
nAP7S Seria XIV 2008

\section{Małgorzata Krzysztofik}

\section{Minucje nowe sowizrzałowe Maurycjusza Trztyprztyckiego - staropolski kalendarz w krzywym zwierciadle satyry}

$\mathrm{P}$ od koniec XVII wieku ukazały się na rynku wydawniczym, w trzech odmiennych wydaniach, Minucje nowe sowizrzałowe ${ }^{1}$ autorstwa Maurycjusza Trztyprztyckiego ${ }^{2}$, stanowiące swego rodzaju sowizdrzalski kalendarz, parodiujący ówczesne almanachy. Utwór jest zręczną kompilacją innych tego typu tekstów - zwłaszcza Kalendarza wiecznego Jana Żabczyca oraz anonimowych $A$-minucji. Zdaniem Karola Badeckiego:

W dobie pełnego rozkwitu polskiej literatury mieszczańskiej, przypadającej na pierwsze dziesiątki lat XVII w., takie humorystyczne kalendarzyki musiały pojawiać się często. Dziś należą one do największych osobliwości bibliograficznych z dwu głównych przyczyn: po pierwsze, że jako lektura poczytna szybkiemu ulegały zniszczeniu; po drugie, że tępiła je zawzięcie cenzura duchowna za różne plugawe wiersze ${ }^{3}$.

Minucje nowe... to odpowiedź na barokowy kalendarz, będący jednym z najpoczytniejszych ówcześnie gatunków literatury popularnej. Warto w tym miejscu przypomnieć, że almanachy XVII-wieczne, oprócz odmierzania czasu, pełniły rolę praktycznych poradników z wielu dziedzin życia (między innymi medycyny, historii

1 Zob. Polska fraszka mieszczańska. Minucje sowiźrzalskie, opr. K. Badecki, Kraków 1948, s. 343: „dwa najwcześniejsze nie wymieniły daty druku, trzecie zaś wyszło w Toruniu w r. 1695".

2 Poeta pochodzenia szlacheckiego, używał również pseudonimu Radopatrzek Gładkotwarski z Lekarzewic.

${ }^{3}$ Polska fraszka mieszczańska..., op. cit., s. XXIX. 
czy geografii świata). Ich funkcję można porównać do znaczenia, jakie w dzisiejszych czasach pełnią środki masowego przekazu — przede wszystkim prasa kobieca. Poeta sowizdrzalski $z$ wielką pasją ośmiesza almanachy, posługując się w tym celu takimi chwytami jak satyra i groteska. Analiza Minucji nowych... daje odpowiedź na zasadnicze pytania wynikające $z$ lektury tekstu: dlaczego Trztyprztycki ośmiesza kalendarze, w jaki sposób to czyni oraz jakim celom ma służyć jego utwór?

Almanachy barokowe posiadały stałą budowę i skonwencjonalizowane słownictwo; składały się z dwóch części (kalendariograficznej i prognostykarskiej), mających określony układ tematyczny oraz formalny. Ich ideologiczną podstawę stanowily najczęściej przesłanki astrologiczne, nie posiadające żadnego racjonalnego odniesienia do rzeczywistości, dlatego kalendarze podawały wiele informacji fałszywych, nierzetelnych i zmyślonych. (Nic więc dziwnego, że w mowie potocznej funkcjonowały przysłowia: „kalendarz wielki lgarz”; „kto kalendarzom, tgarzom wierzy, nie utyje”; „łże jak kalendarz”) ${ }^{4}$. Do tego stanu rzeczy nawiązuje pisarz sowizdrzalski we wstępie do czytelnika, gdzie informuje o prawdziwości swojego tekstu oraz o jego uniwersalizmie: „póki stawać będzie świata”, Minucje... nie stracą ważności, ponieważ Trztyprztycki pisze kalendarz służący na miliony lat i informacje w nim zawarte są prawdziwe, w przeciwieństwie do łgarstw zamieszczonych w kalendarzach krakowskich.

Porównanie budowy Minucji... oraz kalendarzy barokowych nasuwa liczne podobieństwa. Pierwszym zabiegiem wykorzystanym przez satyrę sowizdrzalską jest wykorzystanie tradycyjnego schematu almanachu. Autor wymienia, podobnie do kalendarzy, złotą liczbę oraz okrąg słoneczny, z tym że traktuje te nazwy dosłownie. W tradycyjnej komputystyce średniowiecznej złota liczba służyła do obliczenia daty świąt wielkanocnych, a okrąg słoneczny (cykl słoneczny, czyli 28 lat) stanowil okres, po którego upływie te same dni tygodnia przypadają na te same dni miesiąca. U Trztyprztyckiego złotą liczbę stanowi ilość złota, która jest zawsze większa u pana niż u biedaka, a o okręgu słonecznym dowiadujemy się, że jest większy od Ziemi — obie te informacje są oczywiście zarówno prawdziwe, jak i nieprzydatne dla kalendarzowej funkcji odmierzania czasu.

Następnie pisarz sowizdrzalski przechodzi do wyśmiania kalendarzowego szyfru porządku egzystencjalnego, któremu poświęcona była specjalna rubryka almanachów XVII-wiecznych, zatytulowana na przykład Co czynić albo czego się strzec wedtug aspektów $z$ planetami, zawierająca informacje praktyczne, pozwalające czytelnikowi orientować się w czasie prognostykarskim. Kalendarzyści wymieniali tu wzajemne położenia ciał niebieskich, a następnie pisali, co wolno wtedy robić, a jakich czynności należy zaniechać. Tu teoretyczny aspekt czasu astralnego przekłada się na praktykę codziennego życia, w którym należy przejawiać permanentną czujność, mającą na celu unikanie

${ }^{4}$ Cyt. za: Nowa ksiega przystów i uyrażeń przysłowiowych polskich, red. J. Krzyżanowski, t. 2, Warszawa 1970, s. 9, 346. 
momentów złych oraz maksymalne wykorzystanie dobrych. Umiejętnie odczytana przez sprawnego astrologa machina niebios to szyfr jakości czasu korzystnego oraz zlego, warunkujący powodzenie bądź klęskę ludzkich poczynań — tak oto w kalendarzu na rok 1661 czytamy:

Zlączenie Saturna. Nieszczęśliwy dzień do sprawowania rolej, lekarstw brania, żeglowania i inszych rzeczy. Szesny trzeciak Saturna. Role sprawuj, winnice kopaj, około ogrodów rób, szczep, buduj, z starymi się łącz. Czwartak przeciwny Saturna. Dzień zły do lekarstw, krwie, siania, szczepienia, podróży, osobliwie żeglarskiej, starych i Żydów się chron 5 .

Cechą charakterystyczną tego kalendarzowego „szyfru porządku istnienia” jest dawanie czytelnikowi bardzo konkretnych wskazówek i porad. Przekonanie o wpływie czasu prognostykarskiego na świat podksiężycowy sprawia, że wykonywanie danych czynności w złym momencie jest skazane na niepowodzenie (jak zażycie lekarstwa czy uprawianie roli), natomiast wykonanie ich w czasie dobrym ma gwarantować sukces. Makro- i mikrokosmos przenikają się wzajemnie, tworząc ścisłą sieć zależności; gwiazdy, planety i Księżyc wpływają na skuteczność oraz jakość ludzkich poczynań. Zakres czynności obwarowanych specjalnymi klauzulami jest bardzo różnorodny i pokaźny oraz dotyczy wielorakich aspektów istnienia — od istotnych do błahych. Przestrzeganie zaprezentowanego przez kalendariografię porządku makrokosmosu, wprowadzające w życiu jednostki i całego narodu określony lad istnienia, ma uchronić przed problemami spowodowanymi negatywnym wplywem planet, a przez to ma dawać poczucie życiowego bezpieczeństwa.

Minucje nowe... z pasją ośmieszają podstawy czasu astralnego — pisarz sowizdrzalski wymienia oczywiście za kalendarzem zarówno stosowne odległości kątowe planet, jak i obwarowane regulami temporalnymi czynności, a następnie daje rady uniwersalne, bez odniesienia do czasu prognostykarskiego:

Byś z kalendarzem po ogrodzie chodzil, Gdyś nic nie posial, nie będzieć też rodził ${ }^{6}$.

O powodzeniu ludzkich planów nie decyduje układ planet, ale podejmowanie konkretnych, racjonalnych działań — i tak wyruszenie w daleką podróż bez pieniędzy zawsze jest niebezpieczne, ożenek z wdową nie wróży wiele dobrego, młodej żony trzeba pilnować, a do trybunałów nie warto wybierać się bez środków na „pa-

${ }^{5}$ M. Żórawski, Hemerologeion abo kalendarz świq̨t rocznych i biegów niebieskich z wyborem czasów $i z$ aspektami na Rok Pański 1661... ku dobremu pospolitemu z pilnością uyrachowany, Kraków [1660], druk. Wdowy i Dziedziców Franc. Cezarego, k. A $2 v$.

${ }^{6}$ Polska fraszka mieszczańska, op. cit., s. 290. Dalsze cytaty i lokalizacja za tym wydaniem. 
miętne" dla sędziów. Świat, w którym żyje sowizdrzal, rządzi się regułami prostymi, chociaż niesprawiedliwymi i okrutnymi - wygrywają zawsze bogaci, a biedni muszą przegrać; nie należy oczekiwać sprawiedliwości, bo można doznać zawodu. Smutne prawdy o ludzkim losie są przeplatane radami humorystycznymi - nad ponurą rzeczywistością góruje żywioł śmiechu. Przykładowo, kpiąc z kalendarzowych reguł pouczających czytelnika, kiedy mu wolno zażywać lekarstwo przeczyszczające, autor pisze:

Jeżelibyś tu purgans chciał sprawować, Nie nadążyłbyś gaci odwięzować [s. 291].

Dla wzmocnienia efektu komicznego nie waha się także przed użyciem słów bardziej dosadnych:

Bierz purgans, ale nie leż podle żony, Bobyś ją osrał z tej i z owej strony [s. 292].

Podobnie do świata rządzącego się swoimi regulami, również natura ma określone prawa - erotyka, o której autor mówi zarówno wprost, jak i w licznych aluzjach, stanowi żywiol dominujący w całym tekście. Sowizdrzalskie Opisanie 12 miesięcy na ten Nowy Rok, co znaczy każdy z nich, mające pierwowzór w kalendarzach charakteryzujących pogodę na poszczególne miesiące, sprowadza się do praktycznych porad, jak, kiedy, gdzie i z kim zażywać rozkoszy cielesnych — na przykład:

W maju dobry trunek pijaj,

Grzecznych białychgłów nie mijaj.

Nie wstydź się do wdowy chodzić, Jeśli jej umiesz dogodzić [s. 294].

Nad okrutnym światem góruje pasja permanentnego czerpania radości istnienia sowizdrzalski kalendarz uczy umiejętności korzystania z uciech życia przez cały rok.

Kolejny fragment Minucji nowych... - Praktyka o czterech czessiciach roku nawiązuje do zamieszczanych w części prognostykarskiej barokowych kalendarzy rozdziałów tytułowanych najczęściej: O postanowieniu czterech czéści roku. Do ich istoty należało udzielenie czytelnikowi informacji o momencie rozpoczęcia danej pory oraz krótkie omówienie pogody przewidywanej na podstawie przesłanek astralnych, ewentualnie możliwości wystąpienia określonych chorób. Kalendarzowe opisy pór roku są bardzo do siebie podobne; powielają ustalony schemat wypowiedzi - przykładowo w almanachu Jana Kazimierza Brożeny na rok 1655 czytamy:

Zima, którą poczniemy roku 1654 dnia 21 grudnia god. po południu 1 m. 29, lubo to mrozami pochlebić nam nie obiecuje, jednakże z początku wilgotnymi śniegami zechce nas pogłaskać. Wiosna, którą poczniemy 
dnia 20 marca god. po poł. $1 \mathrm{~m} .13$, z początku pomiernie się nam stawi, ku końcowi ciepła i gorąca doda. Miałaby też panom żołnierzom nieźle posłużyć, więc nie wiem, jeśli sami będą chcieli szczęścia zażyć. Lato, które poczniemy dnia 21 czerwca, god. po połud. $1 \mathrm{~m} .45$, jakoś nas niepokojem nie tylko na powietrzu, ale i na ziemi straszy. Jesień na koniec, którą da Pan Bóg, zaczniemy dnia 22 września, god. na półzeg. przed połud. 7 m. 4, wilgoci, a ku końcowi przymrozki znaczy $[\ldots]^{7}$.

Nie trzeba posiadać wybitnej wiedzy astronomicznej, by móc z pewną dozą prawdopodobieństwa stwierdzić, że wiosna pod koniec będzie cieplejsza, na jesieni wystąpią przymrozki, a w zimie mróz. Prognostyk na temat lata jest zbyt ogólnikowy, można więc na jego podstawie snuć jedynie różnorodne domysły.

Opisy czterech pór roku w innych kalendarzach praktycznie w swej zasadniczej wymowie nie różnią się od siebie, bo przecież istotę czasu astronomicznego stanowi bezwzględna powtarzalność i cykliczność. Każda pora ma sobie właściwe cechy, dlatego autorzy nie muszą zdobywać się na oryginalność, ale wypełniają tę część almanachu treściami ogólnymi, powszechnie znanymi, oczywistymi.

W Minucjach nowych... nieistotne okazuje się wyznaczenie daty rozpoczęcia danej pory astronomicznej czy scharakteryzowanie przewidywanej pogody. Nad opisaniem czterech części roku panuje żywioł nieokiełznanej, wszechpotężnej erotyki — na przykład:

Lecie będą wielkie znoje,

Kiedy się ich złączy dwoje.

I na deszcz się też zaniesie,

Która podołka podniesie [s. 296].

Sowizdrzalski autor, opisując żywioł zabawy, biesiady, erotyki, pijaństwa, przemyca informacje smutne, jak chociażby tę o losie chłopskim:

Nuż kantor zechce kokoszy,

Lub się naprze kilku groszy.

I na drogę dwojga chleba,

Jeszcze i piwa potrzeba.

A tak, jak się rozochocą,

Wniwecz chłopa ogołocą [s. 298].

${ }^{7}$ J. K. Brożena, Kalendarz śuiąt rocznych i obrotów niebieskich z ưvorem czasów i z aspektami na Rok Pański $1655 . . . z$ zilnościa ku dobremu pospolitemu na merydian poznański napisany, Poznań [1654], u Wdowy i Dziedziców Wojc. Regulusa, k. D $3 v$. 
Radość przeplata się w utworze $\mathrm{z}$ goryczą, a ta nieustanna zmiana nastrojów, ambiwalencja uczuciowa, uświadamia, że sowizdrzał się śmieje, ale jest to śmiech przez łzy, typowa dla groteskowego ujęcia świata błazenada połączona z rozpaczą. Świadomość niesprawiedliwości losu oraz krańcowej bezradności, wynikającej z niemożności jego zmiany, sprawiają, że jedynym sensownym sposobem na życie staje się używanie świata.

Fragment Minucji now ch... zatytułowany $O$ wojnie odnosi się do prognostykarskiej partii barokowych kalendarzy, w której autorzy zamieszczali rozdział poświęcony przewidywaniu na dany rok działań wojennych, noszący skonwencjonalizowany tytuł (np. Wojna czy pokój).

Wpisany w dany rok kalendarzowy czas wojny rządzi się w almanachach astrologicznych swoimi prawami. Przede wszystkim pozbawiony jest przyczynowości ludzkiej - kalendarzyści nie omawiają tu żadnych racjonalnych przesłanek, związanych z polityczną mapą Europy, przemawiających za wojną bądź pokojem; pomijają również wewnętrzne problemy Rzeczypospolitej, mające bezpośredni wpływ na jakość i skutki działań militarnych. Nie wspominają o liczebności wojsk czy zagadnieniu obrony twierdz pogranicznych - te wszystkie problemy są poza ich zainteresowaniem, ponieważ czas wojny jest czasem astrologicznym, decyduje o nim nie sytuacja polityczna, ale układ gwiazd i planet na mapie nieba. Jeżeli panem roku jest planeta dobra, zapanuje pokój, jeżeli zła - wojna jest nieunikniona; ten sposób myślenia jest charakterystyczny dla wszystkich kalendarzy astrologicznych epoki ${ }^{8}$.

Dla autora Minucji nowych... czas wojny nie rządzi się ani wplywami planet, ani też wolą Boga; pozbawiony przesłanek astralnych, sprowadza się do przyczynowości ludzkiej. Po zapowiedzi:

Ten rok wszytek niespokojny,

Będziem mieli dosyć wojny [s. 299] —

sowizdrzalski pisarz wylicza zagrożenia wojenne, mając na myśli nie tylko wrogów zewnętrznych Rzeczypospolitej (Turcy, Tatarzy), ale przede wszystkim kłótnie i swary życia codziennego. Bitwy wszczyna pijany chłop, mąż karzący żonę, ubogi dziad z babami w szpitalu, urzędnik pański bije chłopa pracującego w polu, zła żona nie daje spokoju mężowi; nienawiść, kłótnie i spory panują praktycznie wszędzie, czego przyczyna tkwi zarówno w naturze człowieka, jak i w niesprawiedliwości społecznej. Rozdział sowizdrzalskiego kalendarza $O$ wojnie, opisujący kłótnie i bójki toczone przez ludzi na co dzień, ma uświadomić czytelnikowi, że nie planety decydują o bitwach, ale wolna, a zarazem ułomna wola ludzka, skłonna do bójek, a niechętna do przebaczania czy kompromisów. Humorystyczny sposób ujęcia tematu nie tylko bawi czytelnika,

${ }^{8}$ Por. np.: A. Żędzianowski, Rozsq̨dek z guiazd i obrotów niebieskich na rok 1618 ... Wenus tego roku paniq, a Mars idzie za nia, [b. m. i druk.], k. D 6-D $6 v$. 
ale również depatetyzuje pisane poważnym stylem przepowiednie działań militarnych obecne w barokowych kalendarzach. Powagę, nawet grozę sytuacji, rozładowują wulgaryzmy - na przykład:

$$
\begin{aligned}
& \text { Jedna drugą trąci dupą, } \\
& \text { Owa jej w zadek skorupą [s. 300]. }
\end{aligned}
$$

Do stałych elementów budowy kalendarzy astrologicznych baroku należał rozdział zatytułowany Urodzaj polny (lub: O urodzaju polnym), gdzie autorzy przewidywali jakość i ilość plonów w danym roku, o których decydować miał również układ planet na niebie. W kalendarzu Stanisława Słowakowica na rok 1686 czytamy:

Pszenica, miody, orzechy mają przeszkodę od wstecznego Saturna per oppositionem. Żyto od złych Marsa, Miesiąca i Wenery promieni nie wszędy plenne. Owies i jęczmień w takim też zostawać będzie szczęściu, groch, proso, bób, wino Saturni retrogradatio impediet. Len ma dobry znak, ale i ten nie uchodzi kwadratu Saturnowego $[\ldots]^{9}$.

Z powyższego fragmentu wywnioskować można, że ciała niebieskie bezpośrednio wpływają na efekty pracy gospodarza. W kalendarzowej mentalności oprócz makrokosmosu, na jakość i ilość plonów ma wpływ również, a w zasadzie przede wszystkim wola Stwórcy, absolutnie niezależna od niczego i niczym nie przymuszona. Bóg udziela obfitości plonów zgodnie ze swą łaską, ale może też ukarać ludzi klęską nieurodzaju. Przykładowo Marek Freund w kalendarzu na rok 1654 wyjaśnia czytelnikowi, że przyczyną nieurodzajów okazała się kara Boska zesłana na ludzi, którzy nie umieli odpowiednio korzystać z darów Bożych ${ }^{10}$.

Minucje nowe... nawiązują do kalendarzowego rozdziału $O$ urodzajach w sobie wlaściwy sposób — z przekora, ironią i komizmem. Na początku autor niepokoi czytelnika, zapowiadając zły urodzaj:

Muszę prawdę wypisać, niech, kto chce, łaje,

Barzo teraz niedobre będą urodzaje [s. 301] -

a następnie, podobnie jak w rozdziale $O$ wojnie, wymienia przyczyny różnych „nieurodzajów”, które postrzega w nieżyczliwej łasce pańskiej, skłonności ludzi do składania

\footnotetext{
9 S. Słowakowic, Nou'y i stary kalendarz świąt rocznych i biegóu niebieskich, kapłanom dla porządku Kościoła Bożego, gospodarzom dla siania i szczepienia, chorym dla poratowania zdrowia, zdrouym dla traktowania spraw poważnych, myśliuym dla szczwania zuierza wielce stużacy, na Rok Pański $1686 \ldots$ z pilnościa wyrachowany, Kraków [1685], w Druk. Mik. Aleks. Schedla, k. F 2-F $2 v$.

10 Por. Nowy i stary głóuny kalendarz na rok po Narodzeniu Pana i Zbawiciela naszego... 1654... Marka Przyjaciela alias Freunda [k. tyt. zniszczona, nieczytelna], k. F 4.
} 
obietnic bez pokrycia, braku sprawiedliwości. Wielkość plonów, o których rozpisują się barokowe kalendarze, nie zależy tu od wpływów makrokosmosu, ale od ludzkiej pracy:

Jako ich kto posieje, tak się mu urodzą [s. 301].

Sowizdrzalski kalendarz wieczny zapowiada permanentny urodzaj na błaznów, łgarzów, pchły i wszy, których nie zabraknie nigdy. Prawa świata pokazują, że na zło i głupotę „urodzaj” jest zawsze. Odzierając czytelnika ze złudzeń, sowizdrzał jednocześnie dobrze go bawi, o sprawach przykrych i trudnych umie mówić w sposób komiczny.

Pierwowzorem fragmentu Minucji nowych... noszącego tytuł $O$ chorobach jest analogicznie zatytułowany rozdzial prognostykarskiej części kalendarzy barokowych, który miał za zadanie przepowiedzieć czytelnikowi, jakich chorób powinien się on spodziewać w określonych porach roku. Kalendarzyści-astrologowie omawiali tu choroby epidemiczne, występujące powszechnie, których przyczyny upatrywali w układzie planet — tak oto w roku 1605 Bernard z Krakowa rozwiewa obawy czytelników przed morowym powietrzem, zapowiadając równocześnie inne ciężkie choroby:

Nie tylko regentowie doroczni Mars z Saturnusem, ale też i insze konstelacyje, bądź złączenia planetów górnych, bądź też i zaćmienia, tak Słońca, jako i Miesiąca, to obwieszczać rozkazują, iż z łaski Bożej od zarazy powietrza wolni być możemy, acz się poblisko nas, zwlaszcza w krainach wschodnich zawijać tego będzie po części, ale od chorób ciężkich przypadających częścią z wilgotności melankolicznych, częścią też z cholerycznych, $z$ trudna być możemy wolni $[\ldots]^{11}$.

W całym stuleciu siedemnastym popularnym wątkiem kalendarzowego rozdziału o chorobach jest przekonanie o wszechmocy Boga, który może uchronić ludzi przed wszelkimi dolegliwościami (na przykład: „Ten rok za szczególną łaską i prowidencyją Boską od jadowitego powietrza morowego będzie wolny") ${ }^{12}$, w związku z czym usilnie namawia się czytelnika do modlitwy i pokuty — dwu środków ratujących zdrowie. Kalendarzowy rozdział opisujący choroby miał za zadanie przestrzec przed niebezpieczeństwem, ale de facto zarówno ogólnikowość porad, jak i astralny punkt widzenia w żaden sposób nie mogły przyczynić się do poprawy ludzkiego zdrowia.

Sowizdrzalski kalendarz, nawiązując do stylu almanachów XVII stulecia, przepowiada czytelnikowi:

${ }^{11}$ Bernard z Krakowa, Iudicium albo rozsądek i opisanie przypadków rozmaitych za świadectwem influksów niebieskich roku $1605 \ldots$, [b. m. i druk.], k. C 7.

${ }_{12} \mathrm{~J}$. Gostumiowski, Hemerologeion abo nowy i stary kalendarz świq̨t rocznych i biegów niebieskich $z$ uyborem czasów $i$ z aspektami na Rok Pański 1671... uyrachowany, Kraków [1670], w Druk. St. Piotrkowczyka, k. F $1 v$. 
W tym roku będą ciężkie i dlugie choroby,

Dwie bolączki na dole, trzecia u wątroby [s. 302].

Balansując na granicy żartu i powagi, autor kpi z prognostykarskich przepowiedni. Nie pisze o budzących ówcześnie grozę i dziesiątkujących ludność chorobach epidemicznych; jego zdaniem najcięższa w tym roku okaże się „łożna choroba”. Nie zabraknie też lekarzy noszących recepty za dziewkami, które:

[...] będą chorować $\mathrm{z}$ wielkiego urazu,

$\mathrm{Ba}$, i drugiej opuchnie do drugiego razu [s. 302].

Trztyprztycki nie wspomina oczywiście ani o układzie planet, ani o ich wpływie na ludzkie losy; w sowizdrzalskim świecie życie toczy się swoimi torami, nie ma tu miejsca na „influencyje niebieskie”, ale panuje nieokiełznana chęć używania i czerpania radości istnienia.

Kolejny fragment Minucji nourch... pod tytułem Drogi i poselstwa stanowi również nawiązanie do analogicznego rozdziału kalendarzy, gdzie autorzy w niedający się logicznie zweryfikować sposób przewidywali bezpieczeństwo podróżowania w poszczególnych porach roku ${ }^{13}$.

Pisarz sowizdrzalski do problemu dróg i poselstw podchodzi w sposób oryginalny - wymienia drogi niebezpieczne, do których zalicza między innymi chodzenie do cudzej żony, do cudzej komory lub spiżarni, okradanie ludzi. Droga niebezpieczna to droga wiodąca do grzechu — cudzołóstwa czy kradzieży. Porywanie się na nie swoje mienie w sowizdrzalskim poczuciu sprawiedliwości nie popłaca, bo można mało zyskać, a zostać bardzo surowo ukaranym (na przykład więzieniem). Bezpiecznie natomiast można wyprawiać się w zaloty do panny. Nie wolno tracić okazji do miłości, na którą zawsze jest czas i którą zdobywać można nawet podstępem - tu nie panują reguły uczciwości, ale spryt i przebiegłość.

Część Minucji nourych... zatytułowana Ognie i pożogi odnosi się do analogicznego rozdziału kalendarzy epoki, którego celem było przewidywanie, oczywiście na podstawie układu gwiazd, występowania pożarów w danym roku. Każda z planet posiadać miała określoną moc wywierania wpływów na świat podksiężycowy — zwłaszcza Mars, kojarzony z wojną i gorącem, zwiastował panowanie ognia ${ }^{14}$.

Pisarz sowizdrzalski także i tym razem nie odwołuje się do astrologii, którą ignoruje konsekwentnie w obrębie całego utworu, ale z właściwą dozą humoru,

13 Por. idem, Hemerologeion abo nouy $i$ stary kalendarz śuiąt rocznych i biegów niebieskich, $z$ lunacyjami, aspektami i z nich pochodzącym ưborem czasów, na Rok Pański 1672..., Kraków [1671], w Druk. St. Piotrkowczyka, k. F 2.

${ }^{14}$ Por. M. Brożek, Hemerologeion abo kalendarz świąt rocznych i biegów niebieskich, z wyborem czasów i zaspektami na Rok Pański 1667..., Kraków [1666], w Druk. Dziedziców Fran. Cezarego, k. D 2 v.-D 3. 
ze śmiechem przeplatanym ironią, kpi z przepowiedni kalendarzowych - trzeba się spodziewać w tym roku ognia, ponieważ ludzie wynoszą z lasu drzewo i palą w kominach... Taki ogień należy „kropić piwem”, które rozgrzewa i nie tylko nie szkodzi, ale daje radość. Autor wymienia też inny ogień, którego nie da się ugasić, grożący w tym roku czytelnikowi:

Owo zly postrach ogniowy

Koło tlustej bialejglowy. [...]

A żeby się prawdę rzekło,

Gorszy to ogień niż piekło [s. 303].

Dwa kolejne rozdziały Minucji nowych... zatytułowane Odmiana powietrza i O mrozach również nawiązują do prognoz pogody na cały rok, w barokowych kalendarzach zatytułowanych najczęściej $O$ odmianie codziennego powietrza. Słownictwo i styl poszczególnych informacji zasadniczo nie różniły się tam od siebie — należało wymienić miesiąc roku kalendarzowego, podać fazę Księżyca, godzinę na "całym zegarze" (24-godzinnym) lub „półzegarzu” (o najpowszechniejszym współcześnie 12-godzinnym układzie tarczy), wspomnieć o układzie planet i oczywiście o pogodzie w danym dniu roku — dla przykładu:

Pierwszy dzień paźdz[iernika] pogodno, wietrzny nazajutrz, niepewny pogody piątek chmurami niebo okryje, sobota wesoła, niedziela wiatrów nabawi. Pełnia października w poniedziałek po niedzieli różańcowej godz. na półzegarzu $9 \mathrm{~min} .34$ mało nie zleje, nazajutrz pochmurno, insze dni niestatecznej pogody. Ostatnia kwadra października w poniedziałek przed świętą Teresą wesoło chce nastać, i tak znidzie aż do nowiu' ${ }^{15}$.

Maurycy Trztyprztycki, opisując odmianę powietrza, zapowiada „wielkie niepogody”, które będą trapić głupców i złych: błaznów, rozbójników, łgarzy, niedobre kobiety:

Na błazna będzie kapało.

Których też będzie niemało.

$\mathrm{Ba}$ i rozbójcom na lesie

$\mathrm{Na}$ złą chwilę się zaniesie.

A żeby się prawdę rzekło,

I na łgarze będzie ciekło [s. 304].

\footnotetext{
${ }_{15}$ M. Orliński, Kalendarz świąt rocznych i biegów niebieskich, z wyborami czasów i aspektami, na Rok Pański 1653... ku dobremu pospolitemu z pilnością napisany. Święta, suche dni, zaćmienia, rządce roku na suych miejscach znajdziesz, Poznań [b. dr., 1652], k. E 4-E 5.
} 
Autor nie charakteryzuje pogody na poszczególne dni roku, ale moralizuje — łgarze powinni się bać kija, groźniejszego od gradu czy deszczu, złym niewiastom nie pomoże nawet uroda, bo wszędzie dosięgnie je kara.

Opisując mrozy, Maurycy Trztyprztycki stawia sobie cel inny — ukazanie losu ludzi biednych, którzy borykają się z licznymi problemami życiowymi. Ton tej wypowiedzi różni się od poprzedniej - zamiast śmiechu pojawia się powaga oraz gorzka ironia. Świadomość bezradności, niemożności poprawy własnego losu, wiedzie do rozgoryczenia. Biedakowi nic nie pomoże, nawet przychylne konstelacje gwiezdne; jego nocleg jest niepewny, trapią go choroby, męczy strach, zimno, złe traktowanie przez panów. Los ubogiego żaka, którego podstawowe potrzeby bytowe nie zostały zaspokojone, przedstawiony jest realistycznie i obrazowo:

A nuż ubogiego żaka

Nędza w szkole łupi jaka. [...]

Mróz utłucze nieboraka.

Mdleje od rozkoszy prawie,

Gdy leży na gołej ławie [s. 305].

Rozdział opisujący mrozy kończy się trafną uwagą:

Panom a bogaczom wszędzie

Zawsze słońce świecić będzie [s. 306].

Minucje nowe... nie tylko ośmieszają kalendarze epoki, ale również są bardzo ostrą satyrą plebejską, ukazującą jaskrawy podział społeczeństwa na bogatych i ubogich. W tekście sowizdrzalskiego kalendarza emocje nieustannie falują — gorycz miesza się z ironią, śmiech z rozpaczą, radość ze smutkiem, fragmenty humorystyczne przeplatane są poważnymi, co stanowi jedną z najbardziej charakterystycznych cech utworu.

Sowizdrzalska Nauka puszczania kmvie nawiązuje do popularnej ówcześnie metody leczenia różnych chorób, stanowiącej często poruszany temat kalendariografii. W kalendarzowych tabelach czasu powszechną praktyką epoki było zamieszczanie w specjalnej rubryce znaków graficznych informujących o czasie dobrym, lepszym i najlepszym do wykonywania upustów. U podstaw teoretycznych metody tkwiło przekonanie o potrzebie odprowadzenia szkodliwych soków z ciała, sięgające genezą medycyny starożytnej, poparte autorytetem Galena. Z perspektywy nauki współczesnej można oczywiście powątpiewać o skuteczności upustów (mających rzekomo pomóc nawet na kataraktę czy popsute zęby), a rzeczywistość pokazywała, że w niektórych przypadkach wiązały się one z poważnymi skutkami ubocznymi, nawet śmiercią. $Z$ tego właśnie powodu sowizdrzał poddaje metodę krytyce, całkowicie ją ośmieszając:

Miej ode mnie tę przestrogę,

A toć radzę, jako mogę: 
Czasu marnie nie opuszczaj,

Częściej wodę niż krew puszczaj [s. 306].

W Nauce puszczania krwie autor pisze: „niech cię krew nie uwodzi”, „ujdzie cię krew”, „krew puścić” - ale sowizdrzalska nauka, w przeciwieństwie do porad kalendarzowych, nie wyjaśnia czytelnikowi, ani w jaki sposób, ani kiedy dokonywać upustów. Pisarz przestrzega odbiorcę przed wszystkim tym, co może spowodować chorobę, a nawet śmierć; daje rady proste i oczywiste, nad którymi panuje żywioł nieokiełznanego, rubasznego humoru:

Chcesz być i na dole zdrowy,

Chroń się młodej białejgłowy [s. 306].

Liczne zachowania grozić mogą wielorakimi dolegliwościami: skakanie - złamaniem nogi, bywanie u cudzej żony - nieuleczonym bólem, wchodzenie oknem do komory - chorobą, igranie z żelazem - przelaniem krwi.

Ostatni fragment Minucji nowych... opisujący zaćmienia również ma odniesienie do kalendarzy barokowych, które skrupulatnie informowały czytelnika o zaćmieniach Słońca i Księżyca występujących w danym roku oraz o ich rzekomych groźnych skutkach, które trwać miały często wiele miesięcy ${ }^{16}$. Autor Minucji nowych... przewiduje trzy zaćmienia. Pierwsze dotyczy tego, „co żywo nas odziera”:

Z jednej strony żołnierze, a z drugiej Tatarzy,

Nam się to zda jak we śnie, a to coś się marzy.

Żydowie nam wybrali srebro, złoto, młyny,

Że przewodzą nad nami, stare to nowiny [s. 307].

Drugie tegoroczne zaćmienie będzie we młynie, gdzie młynarz dozna olśnienia, „kiedy worów wiele”, a młynarka zabłądzi do skrzyni. Trzecie w karczmie, gdzie łatwo o bójkę, a wtedy:

Gdy się w czoło dostanie, mało co obaczysz [s. 308].

Dosłowna interpretacja słowa potęguje komiczny wydźwięk opisywanych „zaćmień", nie związanych w żaden sposób $\mathrm{z}$ astrologią, lecz mających realny wpływ na ludzkie życie.

Minucje nowe sowizrzatowe to wielopłaszczyznowa parodia i trawestacja kalendarza astrologiczno-prognostykarskiego, uwidaczniająca się w nawiązaniu do jego budowy

16 Por. np. S. Slowakowic, Nowy $i$ stary kalendarz śuiąt rocznych i biegów niebieskich... na Rok Pański $1685 \ldots$, Kraków [1684], w Druk. Franc. Cezarego, k. E $2 v$. 
oraz wykpieniu prezentowanej przezeń ideologii. Sowizdrzalski pisarz ośmiesza almanachy $\mathrm{z}$ wielu powodów. Zakorzenione $\mathrm{w}$ logice astrologicznej, nie miały realnego odniesienia do życia, a głosiły porady zarówno niepraktyczne, jak i bezsensowne. Prezentowana $w$ nich prognostykarska wizja świata i człowieka mijała się z prawdą, światem podksiężycowym zdaniem Maurycjusza Trztyprztyckiego nie rządzą planety, ale twarde i niesprawiedliwe zasady, wobec których jednostka bywa bezradna. To zarazem reguly trwałe, w związku z czym rokrocznie przewidywalne — skąd paradoksalnie plynie „uniwersalizm” kalendarza sowizdrzalskiego: bogatym zawsze będzie się działo dobrze, a biedni będą żyć w nędzy i poniżeniu; ludzka sprawiedliwość będzie przekupna; natura rządzi się swoimi prawami, których nie da się oszukać; głupców zawsze będzie pełno; panowie będą uciskać poddanych, „póki stawać będzie świata” (s. 288). Z tego względu Minucje nowe... to również ostra satyra plebejska, krytykująca realia ówczesnej rzeczywistości, wyrastająca z poczucia absurdalności losu oraz niemożności jego zmiany. Ich autor patrzy na otaczający go świat oczyma realisty, a swoje niejednokrotnie pesymistyczne przemyślenia ujmuje $\mathrm{w}$ formę satyry i przeplata ironią. Wykorzystanie chwytów groteski (widoczne chociażby w niejednolitości nastroju, lączeniu błazenady z elementami rozpaczy), komizmu, ironii, nie tylko w krzywym zwierciadle ukazuje barokowe almanachy, ale również sprawia, że treści poważne czytelnik przyswaja łatwo i z humorem. 